\title{
Organizational Mission Statement Guidelines Revisited
}

\author{
Edward L. Powers, Ph.D., University of North Carolina Pembroke, USA
}

\begin{abstract}
This paper provides appropriate guidelines for writing organizational mission statements. A planning framework is presented as a reference point for seeing where a mission statement fits into the planning process. Examples are provided of guidelines typically recommended for use in writing a mission statement, and some samples of organization mission statements are presented in order to illuminate the variety of approaches used in practice. New guidelines for mission statement content are recommended.
\end{abstract}

Keywords: Organizational Mission Statements; Organization Goals; Mission; Organizational Motto/Slogan

\section{INTRODUCTION}

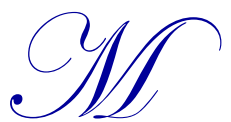

anagement professionals generally agree that the critical first step in planning is the definition of an organizational mission, i.e., a statement which identifies the basic purpose, or business, of the organization (e.g., Ireland \& Hitt, 1992; Vogt, 1994; Schemerhorn, 2006; Cardani, 2011). Also commonly accepted is the idea that a mission statement should address an organization's vision, values, and philosophy, either as separate statements, or alternately, integrated into the mission statement itself (McNamara, 1999). And it appears useful for many organizations to develop a separate slogan (or motto) in order to simplify communications with stakeholders (The Economist, 2009).

Agreement also seems to exist regarding the three main uses of a mission statement (e.g., Economist, 2009; Bart, 1997, Bartkus, 2000): first, as an "umbrella" (mystrategicplan.com, 2011) under which all organizational decisions and endeavors must fit, second, as a means for motivating employees (e.g., Vogt, 1994), and third, as a statement for communicating to stakeholders what the organization is doing (e.g., sound-business-practices.com, 2005, Bartkus, 2000). As an "umbrella," the mission statement provides a focus for what and what not, to do. For example, evangelist Joel Osteen, in an interview on Fox News (2011), said that he "would not comment on politics, because that was not part of his mission." With regard to motivating employees, according to Bart (1997), "good mission statements induce employees to control their own behavior with less formal mechanisms. And to the extent that a mission statement appeals more to the heart than the heads of the workers, greater commitment follows." And with regard to communicating with other stakeholders, Leuthesser (1997) says that "mission statements are widely seen as necessary in helping a company form its identity, purpose, and direction. They are important instruments by which a firm's essential values are conveyed."

But for all of the apparent agreement about the definition and important uses of a mission statement (Lundberg, 1984), universal guidelines for the specific content and characteristics of a mission statement remain elusive. As indicated by Peter Drucker (1954), "Nothing may seem simpler or more obvious than to answer what a company's business is. Actually, [it's]... almost always a difficult question." Graham and Havlick (1994) in their book entitled "Mission Statements" indicate: "Exactly 622 mission statements are included in this book, and no two follow the same exact format, formula, or pattern." Others also (e.g., Bart, 1997; Bartkus, 2000; Hellweg, 2010) underscore how difficult it is to write a meaningful mission statement.

Personal experience and a preliminary literature review suggest four basic issues related to the difficulty in assuring successful mission statements. First is the question of whether or not organizations actually use mission statements in their day-to-day activities (e.g., Morphew, 2006; Stone, 1996). Second is the issue of whether or not 
the use of mission statements has any significant effect on organizational performance (e.g., Pearce, 1987; Sheaffer, 2008). Third is the question of what process should be used to establish an organization's mission (e.g., Lundberg, 1984; Cochran, 2008; Feld, 2008), and most importantly, a fourth issue deals with what the actual components of a mission statement should be (e.g., Alliance, 2005, Vogt, 1994). Although guidelines for writing mission statements are readily available, there does not appear to be universal acceptance of any one particular format or set of attributes (Graham, 1994). Judging from a sample of actual mission statements, organizations tend to pick and choose as they see fit, without any noticeable connection to a set of standard guidelines. And not uncommonly, socalled mission statements often include a mixture of items from the whole planning process, not just a tight statement of organization purpose.

Consequently, since the most pressing issue seems to be the determination of mission statement attributes, the primary purposes in this paper are: (1) to outline the key aspects of the planning process in order to precisely see where a mission statement fits into the big picture, (2) to identify the general guidelines and attributes typically recommended for use in writing corporate mission statements, (3) to provide examples of corporate mission statements, and (4) to propose a more-universal format for mission statement content.

\section{BACKGROUND}

\section{The Planning Context of Mission Statements}

A process approach to defining management normally consists of some variation of five functions: planning, organizing, staffing, leading, and controlling (Wren, 1972). The planning function will then typically include some variation of the steps in Table 1 (Gomez-Mejia, 2012).

Table 1: The Planning Process

\begin{tabular}{|l|l|}
\hline \multicolumn{1}{|c|}{ Steps in Planning Process } & \multicolumn{1}{c|}{ Definitions } \\
\hline Environmental Scanning & *Analysis of Political, Economic, Social, \\
Identify External Influences & Technological environment (PEST) \\
Identification of Stakeholders & $\begin{array}{l}\text { *Analysis of Strengths, Weaknesses, Opportunities, } \\
\text { Threats (SWOT) }\end{array}$ \\
\hline Inventory of Resources & Overall purpose of the organization. \\
\hline Mission (for whole organization) & Specific targets for which to aim. \\
\hline Objectives (for each stakeholder) & Broad plan for achieving each objective. \\
\hline Strategy (for each objective) & Detailed policies, procedures, methods. \\
\hline Operational plans for each strategy. &
\end{tabular}

Once an organization assesses its environment and resources, a mission statement is typically developed as an umbrella under which all subsequent decisions and endeavors must fit. Then, in order to satisfy the mission, the underlying concept in the strategic planning process, i.e., objectives, strategy, operational plans, is that an organization's different stakeholders are the focal points. An organization's long term success at achieving its mission depends partly upon satisfying all stakeholders, and thus separate plans must be developed for addressing the needs of each. American Airlines (www.aa.com), for example, has developed specific objectives to accomplish for each of its basic stakeholders: customers, employees, community, and environment.

But in order for the strategic planning process to be successful, it must be firmly based on a sound mission statement, the guidelines of which are the subject of this paper. And before proposing guidelines, it is important to identify a representative sample of currently recommended guidelines, and a cross section of the many mission statements currently used by organizations.

\section{A Sample of Mission Statement Guidelines}

The many guidelines suggested for writing mission statements may be grouped into two categories: (1) guidelines that address the specific content of a mission statement (Table 2), and (2) guidelines that identify desirable characteristics of mission statements (Table 3). 
Table 2: Mission Statement Content Guidelines

At the very least, your organization's mission statement should answer three questions (Radtke, 1998):

- What are the opportunities or needs that we exist to address? (the purpose of the org)

- What are we doing to address these needs? (the business of the org)

- What principles or beliefs guide our work? (the values of the org)

A good mission statement captures an organization's unique and enduring reason for being, and energizes stakeholders to pursue common goals. It also enables a focused allocation of organizational resources because it compels a firm to address some tough questions: What is our business? Why do we exist? What are we trying to accomplish? (Bart, 1998)

Some possibilities for inclusion in mission statements are (Robbins, 2007):

- Customers: Who are the organization's customers?

- Products or services: What are the organization's major products or services?

- Markets: Where does the organization compete geographically?

- Technology: How technologically current is the organization?

- Growth: Is the company committed to growth and financial stability?

- Philosophy: What are the basic beliefs, values, aspirations, and ethical priorities?

- Self-Concept: What are the major competitive advantage and core competencies?

- Citizenship: How responsive is the organization to societal and environmental concerns?

- Concern for employees: Does the organization consider employees a valuable asset?

Mission statements are intended to focus on essentials, and to summarize the specific core competencies and/or capabilities of the business. (Sound-Business-Practices, 2005)

A mission statement articulates the fundamental purpose of the organization, and often contains several components, among them (Hitt, 2012):

- Company philosophy

- Company identity or self-concept

- Principal products or services

- Customers and markets

- Geographic focus

- Obligations to shareholders

- Commitment to employees

Table 3: Mission Statement Characteristics Guidelines

Mission Statement Guidelines (Palo Alto Software, 2011):

- Make sure you actually believe in your mission statement.

- The best mission statements tend to be 3-4 sentences.

- Avoid saying how great you are, what great quality, and what great service you provide.

- Examine other companies' mission statements, but make certain your statement is you and not some other company.

- The mission statement should be able to withstand time and ultimately have a meaning in the long term standings of the organization.

- The mission statement must be realistic, achievable, and brief.

- An organization's mission statement should be unique. It should portray the individuality of the company.

- Mission statements should be narrow enough to give direction and guidance to everyone in the organization, yet wide enough to allow the business to grow and realize its potential. 
Table 3: Continued

Three keys of Meaningful Mission Statements (Zahorsky, 2007):

- Pass the Mother Test: A mission statement must be a concise paragraph describing what your company does and for whom. Show the mission to your mother, if she does not understand it, start again.

- Self-igniting: Your mission is for you and your business. It does not have to be an earth moving statement. It can be whatever inspires you.

- Value Alignment: Forget the money. A meaningful mission goes beyond the dollars and cents. If your small business is creative, focus on creativity. Try to be what your core competency is.

Essential Features of a Mission Statement (Stone, 1996):

- Clearly articulated

- Relevant

- Current

- Written in positive (inspiring) tone

- Unique to organization

- $\quad$ Enduring

- Adapted to target audience

\section{A Sample of Mission Statements in Practice}

The following samples of mission statements have been selected in order to demonstrate the great diversity in how organizations state their "mission." All of the examples are well-known organizations, and in each instance, the "mission" information appears on their current web page.

\section{United Methodist Church}

Table 4: Two Churches

Mission: To make disciples of Jesus Christ for the transformation of the world.

Four-fold Task:

- We reach out to people and welcome them into the church.

- We relate people to God and help them deepen their relationship with God.

- We nurture people in Christian living.

- We support people in their ministry.

Episcopal Church

Mission: The Episcopal Church strives to live by the message of Christ, in which there are no outcasts and all are welcome. Walking a middle way between Roman Catholicism and Protestant traditions, we are a sacramental and worship-oriented church that promotes thoughtful debate about what God is calling us to do and be, as followers of Christ.

Table 5: Two Fast Food Restaurants

Subway

Goal: To be ranked the number one Quick Service Restaurant (QSR) worldwide while maintaining the great-tasting freshness of our products that is our trademark.

McDonald's

Mission Statement: To be the world's best quick service restaurant experience. Being the best means providing outstanding quality, service, cleanliness, and value, so that we make every

customer in every restaurant smile.

Table 6: Two Manufacturers

Nucor Steel

Mission: Nucor Steel is made up of more than 21,000 teammates whose goals are to take care of our customers. We are accomplishing this by being the safest, highest quality, most productive and most profitable steel and steel products company in the world. We are committed to doing this while being cultural and environmental stewards in our communities where we live and work. We are succeeding by working together.

Philosophy: Ironically, we've gotten big by thinking small. While most of America's steel manufacturers clung to old blast furnace production methods requiring huge integrated steel mills, Nucor pioneered new roads with electric arc furnaces and minimills. We also did something else few manufacturers would ever venture to do; we stripped away management layers and gave all employees, even hourly wage earners, respect, power and rich rewards for doing good work safely. 
Table 6: Continued

DuPont

Mission: Sustainable growth, which we define as the creation of shareholder and societal value while we reduce our environmental footprint along the value chains in which we operate.

Values: Core values are the cornerstone of who we are and what we stand for. They are: safety and health, environmental stewardship, highest ethical behavior, and respect for people.

Vision: To be the world's most dynamic science company, creating sustainable solutions essential to a better, safer, healthier life for people everywhere.

Slogan: Better living through chemistry.

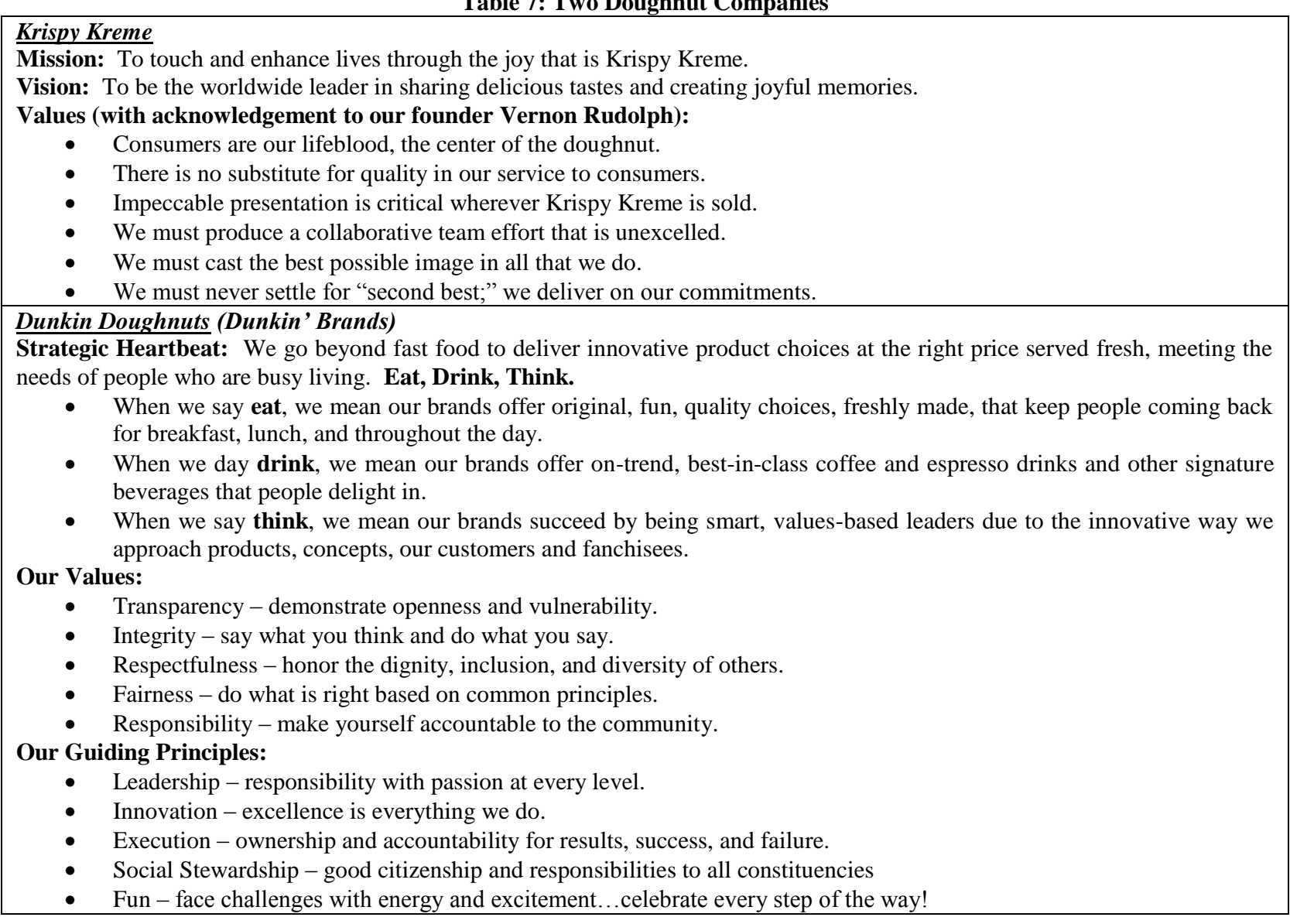

Table 8: Two Retailers

Wal Mart

Mission: To help people save money so they can live better.

Values, Vision: No formal statements.

Slogan: Wal Mart. Low prices. Always.

Target

Mission: To make Target the preferred shopping destination for our guests by delivering outstanding value, continuous innovation, and an exceptional guest experience by consistently fulfilling our Expect More, Pay Less brand promise.

Commitments: To support our mission, we are guided by our commitments to great value, the community, diversity, and the environment.

Slogan: Expect More, Pay Less. 
Table 9: Two Federal Governmental Agencies

Internal Revenue Service

Mission Statement: The mission of the Service is to encourage and achieve the highest possible degree of voluntary compliance with the tax laws and regulations and to conduct itself so as to warrant the highest degree of public confidence in its integrity and efficiency. The service should advise the public of its rights and responsibilities, determine the extent of compliance and the causes of non-compliance, and do all things needed for proper administration and enforcement of the tax laws.

\section{U. S. Postal Service}

Mission Statement: The obligation to provide postal services to bind the Nation together through the personal, educational, literary, and business correspondence of the people. It shall provide prompt, reliable, and efficient services to patrons in all areas and shall render postal services to all communities.

Motto: Neither snow nor rain nor heat nor gloom of night stays these couriers from the swift completion of their appointed rounds.

\section{Table 10: One Top Business School}

Harvard Business School

Mission: We educate leaders who make a difference in the world. For a century, our faculty have drawn on their passion for teaching, experience in working with organizations worldwide, and insights gained from research to educate generations of leaders who have shaped the business in every industry and country around the world.

\section{Keys to Success:}

- The Case Method. Introduced to business education in 1925 by HBS faculty, the case method is a powerful interactive learning process that brings the complex and dynamic realities of business analysis and decision making into the classroom.

- Pioneering research. Contributions range from the creation and development of the field of organizational behavior and marketing to key advances in understanding the nature of leadership, strategy, and decision making. The School's research budget of over $\$ 70$ million is entirely self-funded to ensure objectivity and to provide faculty with the freedom and flexibility to pursue novel and innovative lines of investigation.

- Closeness to practice. The School's commitment to being at the forefront of the current and evolving practice of business has led to education and research programs that reflect the realities of the marketplace.

- International scope. HBS has broad and deep ties with executives, scholars, alumni, and other leaders and their organizations worldwide.

- $\quad A$ vital residential community. HBS is the only top business school in the U. S. with a self-contained, residential campus that forms its own vibrant community in the heart of one of the world's great cities.

- Exceptional resources. Due to the generosity of its alumni as well as the continuing success of its own operations, HBS has exceptional flexibility in meeting the needs of its educational and research activities.

- Our alumni. The best measure of the success of an educational institution is the success of its alumni, and HBS is well known to have one of the largest and most influential alumni networks in the world.

\section{ANALYSIS}

Based upon the mission guidelines (Tables 2 and 3), the sample mission statements (Tables $4-10$ ), and a review of mission statement literature (e.g., Gunelius, 2011; Hagaman, 2010), the following observations are relevant:

- $\quad$ Both guidelines and mission statements typically include elements, e.g., objectives, stakeholders, and strategies, from the planning process in the mission statement (e.g., Robbins).

- Mission statements are sometimes vague to the extent that one could not guess either the name or the nature of the business based only on the statement (e.g.,Wal Mart).

- $\quad$ Both guidelines and mission statements often include terminology that is not well defined, e.g., purpose, integrity, outstanding quality (e.g., Krispy Kreme)

- $\quad$ Organizations have difficulty developing mission, values, vision, and philosophy statements that are clearly differentiated (e.g., DuPont's mission and vision statements).

- Many organizations' "mission" statements include far too many items (e.g., Dunkin' Doughnuts). The result is a fuzzy picture of exactly what the organization is about. Most such examples were too long to incorporate in this paper.

- $\quad$ Mission statements include too many items which are subject to frequent change, and thus needs continual updating, e.g., Nucor mentions its 21,000 teammates. What happens when someone retires? 
- $\quad$ The missions of some organizations are old-fashioned and narrow, and clearly associated with a decline in effectiveness (e.g., U.S. Postal Department).

- $\quad$ Almost all companies have developed mission statements, and most are available on their web homepages.

- $\quad$ Mission guidelines tend to focus on one or more of three categories: (1) specific mission components, e.g. stakeholders, products, (2) general mission characteristics, e.g., short statement, inspiring, unique, and (3) how employees should feel about the mission, e.g. make sure you actually believe in your mission (Palo Alto, 2011), write a mission statement that your company is willing to live (Krattenmaker, 2002).

\section{CONCLUSIONS AND RECOMMENDED GUIDELINES}

Based on the observations from above, and the quasi-consensus about some of the mission statement characteristics, the following recommendations are offered:

\section{The Mission Statement}

A mission statement should simply identify the broad customer need(s) that an organization is going to satisfy. It indicates the organization's fundamental reason for existence. Using this guideline, examples of good mission statements are:

- Wal-Mart: To help people save money so they can live better.

- $\quad$ Harvard: To educate leaders who make a difference in the world.

- $\quad$ United Methodist Church: To make disciples of Jesus Christ for the transformation of the world.

\section{Five Recommended Mission Statement Characteristics}

1. Customer needs focus. The customer, i.e., the target of your goods or services, is the most important stakeholder, and represents the core reason why the organization is in existence. The only true mission of any organization is its customers' satisfaction.

2. Longevity. The mission should contain nothing that will likely need frequent updating. Once other plans, policies, and procedures are developed under this umbrella, and once stakeholders accept its credibility, there must be stability for a reasonable period of time. Of course, as a result of sudden events such as Hurricane Katrina, the World Trade Center 9/11terrorist attack, and the recent U.S. financial crisis, mission statements can become obsolete almost overnight.

3. Simplicity. The mission statement should be reasonably short. One well-written sentence is preferable. If carefully crafted, there should be no need to supplement the mission statement with a motto or separate vision, values, or philosophy statements. These additional items have a tendency to be a confusing distraction from the real message of the mission statement. The simpler, the better.

4. Broad. The recommended rule is that the mission statement should be broad enough that the name of the organization is not immediately evident, but with effort, can reasonably be identified, e.g., "To help people save money so they can live better." Also, it should be broad enough to have room to incorporate future changes in products, markets, strategies, stakeholders, etc., without having to alter the mission statement.

5. Multi-useful. It must be able to simultaneously satisfy the three different uses of mission statements: planning, motivation, and promotion. It should provide clear direction for the development of lower level plans, all employees should clearly understand how it is relevant in their daily work, and all stakeholders should have a clear and realistic vision of what the company is about.

\section{Additional Suggestions About Writing Mission Statements}

- Do not indicate "how" the organization is going to accomplish its mission. This "how" is a part of the strategic planning process.

- Do not identify specific stakeholders in the mission. These are best addressed in the strategic plan.

- Do not include any other aspects of the planning process (Figure 1) in the mission statement. The mission statement should be a stand-alone, uncluttered statement about what the organization hopes to accomplish. 
- $\quad$ The mission statement need not be uniquely different from other organizations' missions. In fact, as a result of the five recommended mission statement characteristics identified above, it would not be surprising for some organizations in the same industry, e.g., religious organizations, to have similar missions. Actually, the strategic planning process is where organizations should typically differentiate themselves from competitors and attempt to establish uniqueness.

- Do not develop a separate vision statement. Properly written, a mission statement can include enough space to allow that the organization still has some distance to go before it's where it hopes to be.

- Delete everything in the mission statement, e.g., number of employees, that is likely to change in a relatively short period of time. While it might be tempting to identify the organization's geographical boundaries, specific products, or specific market segment, these would best appear in the strategic plan.

- Do not identify corporate values unless there is a compelling reason for doing so. And then, be certain to make it clear to the reader how these will be applied regarding relationships to each stakeholder. If you claim to have integrity when dealing with customers, be clear about how integrity is defined.

- Do not include trite phrases such as "number one in the industry," "exceptional quality," or "reliable service." Of course these would be desirable goals. Avoid stating the obvious.

\section{RECOMMENDATIONS FOR FUTURE RESEARCH}

The most important direction of future research is to measure the extent to which the above recommended mission statement format is correlated with successful organizations. While several researchers have focused on estimating the connection between mission statements and organizational performance, their studies attempted to measure performance differences between firms which had missions versus those who did not (Bart, 1997; Sheaffer, 2008; Williams, 2008). Missing was the definition of a particular mission statement format. Future studies need to assess the differential value of different mission formats.

\section{AUTHOR INFORMATION}

Ed Powers is Professor of Management at the University of North Carolina Pembroke. A native of West Virginia, he earned his B.S.B.A. and M.B.A. degrees from West Virginia University, and his $\mathrm{PhD}$ from the University of South Carolina. Previous academic experience includes Clemson University, East Carolina University, and St. Francis Xavier University in Nova Scotia. He teaches management and human resource management courses, and his current research interests are equal employment opportunity, strategic planning, contingency management, and the utilization of management theory in business. E-mail: ed.powers@ uncp.edu or edandmary2000@aol.com

\section{REFERENCES}

1. Abell, D.F. (1980). Defining the Business: The Starting Point of Strategic Planning. Prentice- Hall: Englewood Cliffs, NJ.

2. Bart, Christopher. (1997). Sex, Lies, and Mission Statements. Business Horizons, November/December, 9-18.

3. $\quad$ Bart, Christopher. (1998). Mission Matters. The CPA Journal, v68 n8, 56-57.

4. Bartkus, B., Glassman, M., and McAfee, R. B. (2000). Mission Statements: Are They Smoke and Mirrors? Business Horizons, November-December, 23-28.

5. Cardani, Leann. (2005). Corporate Mission Statement: A Strategic Management Issue. www.stfrancis.edu

6. Cochran, D. S., David, Fred R., and Gibson, C. K. (2008). A Framework for Developing an Effective Mission Statement. Journal of Business Strategies, Vol. 25, No. 2, 27-39.

7. Developing Your Mission Statement. Mystrategicplan.com. (2011).

8. Drucker, Peter F. (1954). The Practice of Management. Harper and Row: New York. p. 49.

9. Feld, Larry. (2008). It's No Secret - You Need a Mission Statement. New Jersey CPA, SeptemberOctober, 22-23.

10. Gomez-Mejia, Luis R., and Balkin, David B. (2012). Management. Prentice Hall: Upper Saddle River, N.J, 197-212.

11. Graham, John W., and Havlick, Wendy C. (1994). Mission Statements. Garland: New York. 
12. Gunelius, Susan. (2011). Five Reasons Why Your Mission Statement Probably Stinks. www.entrepreneur.com, April 29.

13. Hagaman, Gwen. (2010). Examples of Mission Statements That Don't Work. www.brighthub.com, December 9.

14. Hellweg, Eric. (2010). The Eight-Word Mission Statement. www.hbr.org

15. Hitt, Michael A, Black, J. Stewart, and Porter, Lyman W. (2012). Management, $3^{\text {rd }}$ edition. Prentice Hall, Upper Saddle River, New Jersey, 85-97.

16. How to Write Your Mission Statement. (2001). www.entrepreneur.com

17. Ireland, R. D., and Hitt, M. A. (1992). Mission Statements: Importance, Challenge, and Recommendations for Development. Business Horizons, May-June, 38-42.

18. Krattenmaker, T. (2002). Write a Mission Statement that our Company is Willing to Live. Harvard Management Communication Letter, March, 3-4.

19. Leuthesser, L., Kohli, C. (1997). Corporate Identity: The Role of Mission Statements. Business Horizons, May-June, 59-66.

20. Lundberg, Craig C. (1984). Zero-in: A Technique for Formulating Better Mission Statements. Business Horizons, September-October, 30-33.

21. McNamara, Carter. (1999). Basics of Developing Mission, Vision and Values Statements. www.managementhelp.org

22. Mission Statement. (2009). www.economist.com

23. Morphew, C. C., and Hartley, M. (2006). Mission Statements: A Thematic Analysis of Rhetoric Across Institutional Type. Journal of Higher Education, Vol. 77, No. 3, May/June.

24. Osteen, Joel. (2011). Interview. Fox News TV, March 6.

25. Pearce, J. A., and David, Fred. (1987). Corporate Mission Statements: The Bottom Line. Academy of Management Executive, Vol. 1, No. 2, 109-116.

26. Radtke, Janel M. (1998). How to Write A Mission Statement. The Grantsmanship Center Magazine, Fall. WWw.tgci.com

27. Robbins, Stephen P., and Coulter, Mary. (2007). Management, $9^{\text {th }}$ edition. Upper Saddle River, New Jersey: Prentice-Hall, 210-11.

28. Schermerhorn, J. R. (2006). Management, $8^{\text {th }}$ edition. Wiley: New York, 221-223.

29. Sheaffer, Z., Landau, D., and Drori, I. (2008). Mission Statement and Performance: An Evidence of "Coming of Age." Organization Development Journal, Vol. 26, No. 2, 49-62.

30. Stone, R. A. (1996). Mission Statements Revisited. Sam Advanced Management Journal, Winter, 31-37.

31. Tarnow, Eugene. (1998). A Recipe for Mission and Vision Statements. www. refresher.com.

32. The Management of Mission Statements and Mission Statement Insight. (2005). www.Sound-BusinessPractices.com

33. Toftoy, C. N., and Chatterjee, J. (2004). Mission Statements and the Small Business. Business Strategy Review, Autumn, 2004, 41-44.

34. Vogt, Jean. (1994). Demystifying the Mission Statement. Nonprofit World, Vol. 12, No. 1, January/February, 29-32.

35. What's in a Mission Statement? (2005). www.allianceonline.org

36. Williams, Linda S. (2008). The Mission Statement. Journal of Business Communications. Vol. 45, No. 2, April, 94-119.

37. Wren, D. A. (1972). The Evolution of Management Thought. Ronald Press: New York, 414.

38. Writing a Mission Statement. (2011). Palo Alto Software. Eugene, Oregon.

39. Zahorsky, D. (2007). Writing A Meaningful Mission Statement. www.sbinformation.com 
International Journal of Management \& Information Systems - Fourth Quarter $2012 \quad$ Volume 16, Number 4 NOTES 